\title{
BEYOND R. v. SAULT STE. MARIE: \\ THE CREATION AND EXPANSION OF STRICT LIABILITY AND THE "DUE DILIGENCE" DEFENCE
}

\section{N.J. STRANTZ*}

The Supreme Court of Canada decision in R. v. Sault Ste. Marie created strict liability offences as a middle ground between mens rea offences and absolute liability offences. Strict liability offences allow the defence of due diligence, where the accused has exercised a reasomable standard of care in protecting against the event which occurred. This article examines the acceptance, incorporation and development of strict liability offences and the due diligence defence by Canadian courts, legislatures and industry. In Canadian courts, strict liability and the due diligence offence arise in quasi-criminal, public welfare offences. The reverse onus imposed by the due diligence defence was challenged and upheld in a Charter case. Cases have shown that corporations and directors may be held directly and vicariously liable for the actions of employees and contractors under strict liability principles. Legislatures at both the provincial and federal level have incorporated strict liability and the due diligence defence into a wide variety of quasicriminal statuses. Industry has responded by taking positive steps to ensure it is complying with legislated standards. The article notes that strict liability is a logical and timely development for Canadian law, as the "due diligence" defence encourages industry's co-operative efforts in the protection of the public interest without hindering regulatory and legal enforcement of public welfare legislation.
La décision rendue par la Cour suprême du Canada dans la cause R. c. Sault Ste. Marie a placé les contraventions de droit strict à mi-chemin entre les infractions exigeant la mens rea et les infractions de responsabilité absolue. Les contraventions de droit strict permettent de recourir an mécanisme de défense applicable à l'obligation de prudence et de diligence, ef d'imoquer que raccusé a pris les mesures nécessaires pour empêcher l'événement qui est survenu. Le présent article cxamine r'acceptation. l'incorporation er le dév'eloppentem des contraventions de droit strict ef du mécanisme de défense imoquant les mesures nécessaires par les tribunaux. lés législatures et l'industrie canadiens. Dans les tribunaux canadiens, les contraventions de droit strict et la défense des mesures nécessaires som invoquées dans le cas des infractions quasicriminelles contre le bien-être public. L'inversion de la charge de la prewe imposée par le mécanisme de défense applicable à l'obligation de prudence et de diligence a été remise en question et accueillie dans un cas relevam de la Charte. Cértaines causes ont montré que, selon les principes de la responsabilité stricte, les sociétés et les directeurs peuvem être tenus directemem responsables des actes de leurs employés et contractants. Tant au niveau provincial que fédéral, les législatures ont incorporé les contraventions de droit strict et la défense ci-dessus mentionnée dans une grande variété de statuts quasicriminels. L'industrie a réagi en prenant des mesures positives pour assurer le respect des normes légiférées. L'article note que la responsabilité stricte constitue une évolution logique et à propos du droit canadien - la défense applicable à robligation de diligence encourageant les efforts coopératifs visant la protection de lintérêt public sans gêner l'application des réglements et des lois assurant le bien-être public.

\section{TABLE OF CONTENTS}

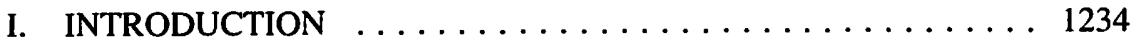

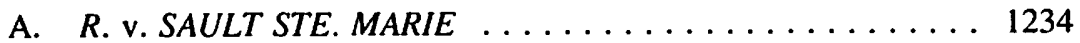

B. STRICT LIABILITY AND THE "DUE

DILIGENCE" DEFENCE . . . . . . . . . . . .

Nancy Jean Strantz, LL.B., J.D., Barrister and Solicitor, Calgary, Alberta. 
II. LEGAL DEVELOPMENTS . . . . . . . . . . . . . . . . . . 1237

A. BURDEN OF PROOF

AND PRESUMPTION OF INNOCENCE . . . . . . . 1237

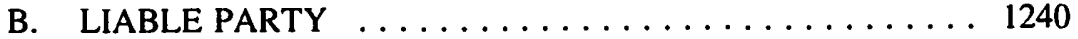

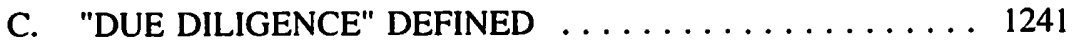

III. LEGISLATIVE DEVELOPMENTS $\ldots \ldots \ldots \ldots \ldots \ldots \ldots \ldots 1244$

A. SCOPE OF APPLICATION OF STRICT
LIABILITY TO LEGISLATION $\ldots \ldots \ldots \ldots \ldots \ldots \ldots 1244$

B. STATUTORY "DUE DILIGENCE"

IN THE 1990 's . . . . . . . . . . . . . . . . . . . . 1248

IV. PRAGMATIC DEVELOPMENTS

IN INDUSTRY . . . . . . . . . . . . . . . . . . . 1249

A. CORPORATE POLICIES $\ldots \ldots \ldots \ldots \ldots \ldots \ldots \ldots 1251$

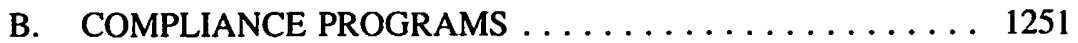

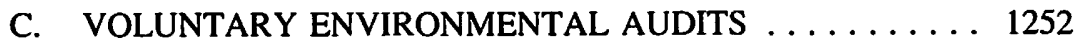

D. RISK ASSESSMENT $\ldots \ldots \ldots \ldots \ldots \ldots \ldots \ldots \ldots \ldots$

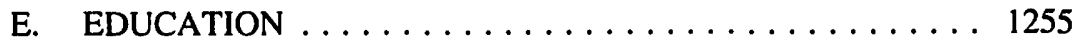

F. COMMERCIAL DRAFTING $\ldots \ldots \ldots \ldots \ldots \ldots \ldots 1256$

V. CONCLUSORY COMMENTS $\ldots \ldots \ldots \ldots \ldots \ldots \ldots \ldots . \ldots \ldots$

\section{INTRODUCTION}

Great jurisprudential decisions often have rather humble beginnings. $R$. v. Sault Ste. Marie $^{1}$ is one such decision. Sault Ste. Marie arose out of an attempt by a municipal government to avoid liability for polluting a public waterway. Ironically, the judicial offspring of this case, strict liability and "due diligence," have become part of the driving force encouraging corporate responsibility towards, and regulatory protection of, public interests. This article is an overview of the legal, legislative and pragmatic developments of the last fifteen years resulting from the creation and expansion of strict liability and the "due diligence" defence.

As a preliminary comment, it should be noted that "strict liability" is a term that is sometimes used interchangeably with "absolute liability" to refer to liability irrespective of fault. However, this use of the term in this context is inaccurate because the defence of due diligence may be used to avoid strict liability, whereas absolute liability, strictly speaking, is liability for which there is no defence. ${ }^{2}$ For the purposes of this article, the terms "strict liability" and "absolute liability" refer to two distinct types of liability.

A. R. v. SAULT STE. MARIE

In 1972, the City of Sault Ste. Marie was charged with discharging, or causing or permitting to be discharged, refuse pollution into two watercourses, all of which was in

R. v. Sault Ste. Marie, [1978] 2 S.C.R. 1299, 85 D.L.R.(3d) 161; 40 C.C.C.(2d) 353; 3 C.R.(3d) 30 (S.C.C.) [hereinafter Sault Ste. Marie] cited to the S.C.R.

2. An example of a case resulting in absolute liability as this term is used in this article is: Rylands $\mathrm{v}$. Fletcher (1866), L.R. 1, Ex. 265; affd. [1868] L.R. 3, H.L. 330. 
contravention of the Ontario Water Resources Act. ${ }^{3}$ The Ontario Provincial Court (Criminal Division) acquitted the City at trial, but a trial de novo was ordered on appeal by the Crown. At the subsequent trial, the City was convicted on the basis that mens rea was not required and the City could thus be vicariously liable for its contractor's acts. On appeal by the City, this conviction was quashed by the Divisional Court on grounds that the charge was duplicitous. The Divisional Court found the offence was not one of "absolute liability" and that mens rea must be proved. On a further appeal by the City raising a technical argument involving the issue of duplicity, the Ontario Court of Appeal found that mens rea was an essential element of the offence, but that the evidence was insufficient to establish the existence of mens rea. Another trial was therefore ordered. Finally, the Supreme Court of Canada granted leave to appeal to the Crown, and leave to the City to cross-appeal, on the issues of duplicity and mens rea, so that the parties might at long last be able to litigate the underlying charge.

In 1978, the Supreme Court of Canada ordered a new trial, and dismissed both appeals. It chose not to agree with either party's polarized approach to mens rea and liability. In its unanimous decision, the Court instead applied the concept of "strict liability" to public welfare prohibitory provisions, and introduced the corresponding defence of "due diligence." Sault Ste. Marie thus became the seminal case for the judicially created "due diligence" defence in cases involving violation of prohibitory provisions in public welfare legislation.

\section{B. STRICT LIABILITY AND THE "DUE DILIGENCE" DEFENCE}

Prior to Sault Ste. Marie, violations of public welfare legislation often created absolute liability on the part of the offender. The high standard of care imposed by absolute liability was thought to protect societal interests by creating a deterrence in instances where an individual or corporation engaged in activities which carried a higher risk of harm or damage to others. ${ }^{4}$ Absolute liability was also perceived as being the most administratively efficient and effective means of ensuring corporate compliance with legislation, as it eliminated the difficult task of proving intent on the part of a corporate offender. ${ }^{5}$

Strict liability, as defined in Sault Ste. Marie, has been termed a "halfway house"6 between fault-based liability (for example, criminal liability), which requires proof of mens rea, and absolute liability, where the presence or absence of mens rea or intent is irrelevant and liability results once mere commission of the prohibited act is proved. Traditionally, the courts limited themselves to an unsatisfactory choice between requiring

3. The Water Resources Act, R.S.O. 1970, c. 332, s. 32(1), now s. 16(1).

4. The court in Sault Ste. Marie disagreed. For a discussion of the policy issues see supra, note 1 at 1310-12; R. Cotton. "Due Diligence and Prevention" in Environmental and Health and Safety Investigations (Mississauga: Insight Educational Services, 1989) at 14.

s. Ihid.

6. R. v. Sault Ste. Marie, stupra, notc 1, at 1313 (per Dickson J. quoting Dr. Glanville Williams) and S.C.R. at 1327. Also see A.C. Hutchinson, Sault Ste. Marie. Mens Rea And the Halfway House: Public Welfare Offences Get a Home of Their Own (1979) 17 (No.2) Osg. H.L.J. 415. 
proof of intent (which sometimes effectively nullified legislation by making it virtually impossible for the prosecuting party to prove its case against a corporate violator), or not requiring proof of intent (with the unfair result that the merely negligent offender could be found as culpable as those guilty of flagrant or intentional violation). ${ }^{7}$ Thus, the introduction of strict liability created a means by which the courts could both discourage "latently pernicious activities" and take into account the "generally held repulsion against punishment of the morally innocent."

Proof of intent or mens rea is not a required element of a strict liability offence; but once a prima facie case is made out, liability may be avoided if, on a balance of probabilities, the accused can show it used "due diligence" to avoid the event giving rise to prosecution. "Due diligence" is shown when a party has taken "all reasonable steps to avoid the particular event."9 The determination of what will amount to "reasonable steps" will be contingent on the nature of the offence, the specific industry involved, and the individual circumstances of each case.

Although Dickson J.'s judgment in Sault Ste. Marie has been lauded as progressive and practical, its historical foundations have been found lacking by some, and the case has been criticized as one of "judicial law-making." 10 It is complained that Dickson J. gave considerable weight to lower court decisions which the Supreme Court of Canada previously "studiously ignored...or steadfastly refused to follow."11 Critics note that Sault Ste. Marie adopts an approach to liability recommended only in dissent in an Ontario Court of Appeal decision, ${ }^{12}$ although a review of cases involving the same Ontario legislation at issue in Sault Ste. Marie ${ }^{13}$ indicates that, prior to Sault Ste. Marie, some Ontario courts had taken this same approach, and had allowed evidence of an absence of fault or neglect in preventing harm to be used as a defence to liability. ${ }^{14}$ The decision did, however, go against a plethora of decisions in which the courts had followed the traditionally polarized approach by choosing "not to consider the possibility or validity of some middle ground of liability". ${ }^{15}$

7. Hutchinson, supra, note 6 at 416.

8. R. v. Sault Ste. Marie, supra, note 1 at 1310.

9. R. v. Sault Ste. Marie, supra, note 1 at 1326.

10. Dickson J. himself admitted the concept was a "judicial creation founded on expediency," but noted that "the concept of absolute liability and the creation of a jural category of public welfare offences are both the product of the judiciary and not of the Legislature," and that case "offers the opportunity of consolidating the clarifying the doctrine" : R. v. Sault Ste. Marie, supra, note 1 at $1310,1325$.

11. Also see A.C. Hutchinson, supra, note 6, at 420 et seq., with references to cases cited in Sault Ste. Marie, supra, note I at 1316, Re: motor vehicle offence - R. v. Mclver, [1966] S.C.R. 254 (S.C.C.) aff'g [1965] 2 O.R. 475, [1965] 4 C.C.C. 182 (Ont.C.A.); re: liquor offences - R. v. Regina Cold Storage \& Forwarding Co. (1923), 41 C.C.C. 21, [1923] 3 W.W.R. 1387 (Sask. C.A.) and R. v. Laroque (1958), 25 W.W.R. 434, 120 C.C.C. 246 (B.C.C.A.); re: food and drug offences - R. v. Custeau (1971), 6 C.C.C. (2d) 179, [1972] 2 O.R. 250, 17 C.R.N.S. 127 (Ont.C.A.). R. v. Hickey (1977), 13 O.R. (2d) 228, 70 D.L.R. 689 (Ont.C.A.) rev'g (1976), 12 O.R. (2d) 578, 68 D.L.R. (3d) 88, 29 C.C.C. (2d) 23 (Ont. H.Ct).

13. Water Resources Act, R.S.O. 1980, c. 361, s. 32(1).

14. Hutchinson, supra, note 6 at 446.

15. Hutchinson, supra, note 6 at 446. Also see $R$. v. Sault Ste. Marie, supra, note 1 at 1312-13. 
In spite of any perceived weaknesses, Sault Ste. Marie has, in fact, delineated a thriving new area of the law. Discussions of strict liability and "due diligence" can be found in well over a hundred reported cases since that 1978 decision, and federal and provincial statutes now include wording to explicitly permit "due diligence" as a defence. Moreover, particularly in the environmental area, industry has responded to these developments by implementing new policies and practices to take advantage of both statutory and judicially-created "due diligence" defences. By changing the legal and business considerations necessary for proper risk analysis, Sault Ste. Marie is part of a significant change in the way Canadian industries are conducting business. The balance of this article discusses these legal, legislative and pragmatic developments.

\section{LEGAL DEVELOPMENTS}

As with the introduction of any new legal principle, the introduction of strict liability by Sault Ste. Marie resulted in some uncertainty in the law. Definition of the types of legislation that gives rise to strict liability is one issue that has been judicially determined. ${ }^{16}$ Whether statutory requirements making defendants "prove" or "establish" their "due diligence" violates the presumption of innocence under Section 11(d) of the Canadian Charter of Rights and Freedoms ${ }^{17}$ has been another litigated issue. Other judgments have delineated the parties to whom strict liability will attach, and have defined "due diligence" in relation to those parties and their proscribed activities. An overview of the key jurisprudential issues follows.

\section{A. BURDEN OF PROOF AND PRESUMPTION OF INNOCENCE}

Strict liability creates a middle position between criminal offences (which, due to the severity of the penalties they carry, require proof of mens rea so as to protect the fundamental rights of the accused), and absolute liability offences (where the potential harm or damage is so great that the legislators deem guilt to follow proof of the proscribed act without any reference to any accompanying state of mind). Basically, the "due diligence" defence operates to shift the burden of proof. Just as in criminal or absolute liability cases, initially the Crown must prove the commission of the proscribed act by the defendant by a criminal standard of proof (ie. beyond a reasonable doubt). Once a prima facie case is made out, a conviction will result without a showing of negligence, unless the defendant adduces evidence which shows, on a balance of probabilities, that it acted with "due diligence" and without negligence. ${ }^{18}$

The issue as to whether the "due diligence" defence violates Section 11(d) of the Canadian Charter of Rights and Freedoms (the "Charter") surfaced in 1989. An Ontario

16. See section 3 of this paper entitled "Legislative Developments."

17. Canadian Charter of Rights and Freedoms, Part I of the Constitution Act, 1982, being Schedule B of the Canada Act, 1982 (U.K.), 1982, c. 11, s. 11:

Every person charged with an offence has the right

(d) to be presumed innocent until proven guilty according to law in a fair and public hearing by an independent and impartial tribunal.... 
Court of Appeal decision ("Wholesale Travel"), dealing with a false or misleading advertising offence under the federal Competition Act, ${ }^{19}$ held that a statutory provision requiring an accused to "establish" "due diligence" equated to a requirement for proof of reasonable care on a balance of probabilities. This requirement was found to place too great a burden on the accused, thereby violating the presumption of innocence in section 11(d). The Court agreed with the defendant that legislation could, at most, require the accused to raise a "reasonable doubt" as to whether the accused exercised due diligence. ${ }^{20}$ Given its devastating implications for the enforceability of Canadian regulatory legislation, it was not surprising that the appeal of this decision to the Supreme Court of Canada was joined by the interventions of six provincial governments, and a corporation whose own provincial appeal case had involved the same issue. ${ }^{21}$

At the same time Wholesale Travel was proceeding through the courts, section 11(d) arguments were also being made in cases dealing with Ontario's Occupational Health and Safety Act, $^{22}$ and the federal Customs Act. ${ }^{23}$ The courts in these cases noted that having to prove "due diligence" on a balance of probabilities, as opposed to merely raising a reasonable doubt, was a factor of crucial importance to a conviction. These courts concluded that statutory provisions that create an onus to prove "due diligence" virtually required conviction irrespective of whether a reasonable doubt existed as to guilt, and that this was a clear infringement of section 11(d) of the Charter. Furthermore, these courts found that this infringement was not a "reasonable limit" on the presumption of innocence permitted by Section 1 of the Charter. Section 1 was found to be inapplicable because "taking away the right of an accused to the benefit of the reasonable doubt was disproportionate to the object of the Act [safety of workers] because it did not impair as little as possible that protected right."24 In short, these decisions not only confirmed that

R. v. (Wholesale) Travel Group Inc. (1989), 63 D.L.R. (4th) 325, 35 O.A.C. 331, [1989] 70 O.R. (2d) 545 rev'g in part (1988), 23 C.P.R.(3d) 92, 46 C.R.R. 100 (Ont.H.C.) rev'g (1988), 22 C.P.R.(3d) 328 (Ont. Prov. Ct); granted leave to appeal in (1990) 65 D.L.R. (4th) vii (note), 106 N.R. 79 (note) (S.C.C.). Decision by S.C.C. dismissed accused's appeal and allowed the Crown's appeal in part: sec $R$. v. Wholesale Travel Group Inc. and Chedore (1991), 130 N.R. I (S.C.C.). $R$. v. (Wholesale) Travel Group Inc. (Ont.C.A.), supra, note 19; also see R. Cotton \& M. Donahue, "Key Aspects of the Environmental Legislative and Regulatory Regime Governing Canadian Mining" in course materials published in Environmental Regulations Compliance Management for Canadian Mining, (Toronto: The Canadian Institute, 1991) at 48.

Dickson J. does not appeared to have contemplated this problem. In Sault Ste. Marie, he noted that the burden of proving due diligence was logically that of the defendant, as he was the only one who would generally have the means of proof. He further noted that this seemed fair, "as the alternative is absolute liability which denies an accused any defence whatsoever": $R$. v. Sault Ste. Marie, supra, note 1 at 1325. The Attorneys General of Ontario, Quebec, New Brunswick, Manitoba, Saskatchewan and Alberta all intervened, as did Ellis-Don Limited. (Ont. Dist. Ct.) (and for a historical overview of the issue through the Ontario courts, see the Editorial Note at 133-34 preceding the decision); R. v. Ellis-Don Ltd. (and Others), [1991] I O.R. (3d) 193.

2.. $\quad R$ v. Ireco Canada II Inc. (1988), 65 C.R. (3d) 160, 29 O.A.C. 161,43 C.C.C. (3d) 482 (Ont. C.A.). Also see R. v. Multitech Warehouse Direct (Ontario) Inc. (1989), 52 C.C.C. (3d) 175 (Ont. C.A.). R. v. Ellis-Don Ltd. (and Others), supra, note 22, at 193. 
the burden of proof violated Section 11(d) of the Charter, they also held that the impugned provisions could not be justified under Section 1 of the Charter.

In February 1991, the Wholesale Travel appeal came before the Supreme Court of Canada. In its written decision rendered in October $1991,{ }^{25}$ the Court found that the reverse onus on the accused to establish "due diligence" violated the presumption of innocence under the Charter. However, the Court found that this limit on a fundamental right was justified under section 1 of the Charter because the provision in question was of sufficient importance to override the rights constitutionally protected under section 11(d), and because the provision's encroachment on the constitutionally protected right was not excessive given the objectives of the legislation. ${ }^{26}$ The Court, however, qualified the scope of application of this decision by noting that the interpretation of Charter provisions will depend on the legislative context to which the Charter is being applied. The Court noted that section 11(d) "may have different scope and implications in a regulatory context than in a truly criminal one, ${ }^{127}$ and that "constitutional standards developed in the criminal context cannot be applied automatically to regulatory offences" because of both the "distinctive nature of regulatory activity," and the "fundamental need to protect the vulnerable. ${ }^{128}$

Broadly stated, the result of Wholesale Travel is that section $11(\mathrm{~d})$ of the Charter will not be available to shelter persons from liability for their proscribed activities in a regulated sphere of business. ${ }^{29}$ Thus, where an offence is shown to be regulatory and non-criminal in nature, strict liability will be operative and the defence of "due diligence" will be available.

R. v. Wholesale Travel Group Inc. and Chedore, supra, note 19. The decision was rendered October 24. 1991.

26.

The two-part test used to determine when a statutory limitation on a fundamental right or freedom is permitted under section 1 of the Charter is described by Lamar, C.J.C. in $R$. v. Wholesale Travel Group Inc. and Chedore, supra, note 19 at 93-94, quoting R. v. Chaulk and Morrissette, [1990] 3 S.C.R. 1303 at $1335-1336$, as follows:

(1) The objective of the impugned provision must be of sufficient importance to warrant overriding a constitutionally protected right or freedom: it must relate to concerns which are pressing and substantial in a free and democratic society before it can be characterized as sufficiently important;

(2) Assuming [(1)]..., the means chosen to achieve the objective must pass a proportionality test; ...they must:

(a) be 'rationally connected' to the objective and not be arbitrary, unfair or based on irrational considerations:

(b) impair the right or freedom in question as 'little as possible'; and

(c) be such that their effects on the limitation of rights and freedoms are proportional to the objective.
$R$. v. Wholesale Travel Group and Chedore, supra, note 19 at 25.

Ihid. at 25-26.

For a general discussion of the differential treatment of regulatory offences, see $R$. v. Wholesale Travel Group Inc. and Chedore, supra, note 19 at 27-36. 


\section{B. LIABLE PARTY}

The determinant of which parties will be held responsible for strict liability offences is "control." As Dickson J. explains: "The element of control, particularly by those in charge of businesses activities which may endanger the public, is vital to promote the observance of regulations designed to avoid that danger." ${ }^{30}$ Control may take the form of "supervision or inspection, by improvement of ... business methods or by exhorting those whom [a person] may be expected to influence or control. ${ }^{131}$

Corporate liability for a public welfare offence results from the offending acts of those who are a corporation's "directing mind and will" - the directors and officers who are in "control" of the corporation's operations. ${ }^{32}$ Several Ontario cases suggest that, unless "due diligence" is shown, both the corporation and the directing mind will always be liable, either as joint principals or as principal and accessory, when the offending act is committed by an officer who is so in control that the act becomes the corporation's act as well as his own. ${ }^{33}$ However, to successfully prosecute officers and directors, the Crown must prove direct participation in or, at minimum, knowledge of the offence by the officers or directors. ${ }^{34}$ Co-existing liability of both a company and its officer is not vicarious; "each is independently liable because each could have prevented the offence." 35

An employer may be directly liable for failing to meet a statutory duty imposed on it. The two-part inquiry the court makes to establish direct liability of the employer is:

(1) Did the Defendant control the activity undertaken?

(2) While the activity was undertaken, were workers exposed to a harmful situation? ${ }^{36}$

R. v. Sault Ste. Marie, supra, note 1 at 1322.

Ibid. per Dickson J. quoting Evershed L.J. in Lim Chin Aik v. The Queen, [1963] A.C. 160 at 174. This principle was recently reaffirmed in $R$. v. Bata Industries Ltd., (7 February 1992) Doc. No. 9200049 (O.J. No 236) (O.C.J., Prov. Div.) [unreported] per Ormston D.J. Also reported in AL NEWS, "Bata fine for leak sets precedent," Toronto, Globe and Mail (8 April 19920 at A7.

R. v. N.M. Paterson and Sons Limited, [1980] 2 S.C.R. 679, [1981] W.W.R. 103, 19 C.R.(3d) 164, 7 Man. R.(2d) 382, 55 C.C.C.(2d) 289, 117 D.L.R.(3d) 517, 34 N.R. 597 (S.C.C.).

$R$. v. Fell (1981), 64 C.C.C. (2d) 456 (C.A.); R. v. Shamrock Chemicals Lid. (1989), 4 C.E.L.R. (N.S.) 315 (Ont. Dist. Ct.).

R. v. Fell, supra, note 33. For a general discussion of liability of corporate officers and directors see R.M. McLeod, "Environmental Protection Legislation: Personal Liability of Officers and Directors" (1988) 5 (No. 3) Bus. \& L. 20.

35. $\quad$ D. Saxe, "Fines Go Up Dramatically in Environmental Cases" (1989) 3 C.E.L.R. (N.S.) 104 at 108; sec R. v. Texaco Canada Inc. (1984), 13 C.E.L.R. 124 (Ont. Prov. Ct.) aff'd (1986), 1 C.E.L.R. (N.S.) 100 (Ont. Dist. Ct.): R. v. Placer Developments Ltd., [1983] N.W.T.R. 329, 28 C.R. (3d) 225, 38 A.R. 197 (S.C.), additional reasons at [1983] N.W.T.R. 351, 12 C.E.L.R. 58, 49 A.R. 227 (S.C.), and particularly per Stuart J. in N.W.T.R. at 377.

See Varnicolor Chemical Lid. case [unreported] in which a consultant was charged. [Trial held April $11 / 12,1991$ with judgment reserved]. 
In addition to its direct liability, a corporation, as an employer, may be found vicariously liable for the strict liability offence of its employee, either separate from or in addition to the direct liability of the corporation's employee who fails to exercise due care.

In certain cases, the owner of property may be liable for offences committed with that property. For example, in cases involving motor vehicle violations, the vehicle owner may stand in a similar position to that of an employer, being held strictly liable for another's conduct. ${ }^{37}$

As one might expect, the "due diligence" defence is available to both individuals and corporate entities - even ships accused of strict liability offences. ${ }^{38}$ As the nature of the offence will depend on the type of party charged, so also will the type of "due diligence" required to exculpate the parties differ. For example, an employer may be found innocent of the violations of an employee if the employer acted reasonably to induce his employee to comply with the legislation, ${ }^{39}$ whereas the employee may be liable for committing the violating act.

A consultant or contractor hired by the corporation may be directly liable. ${ }^{40}$ However, the fact a contractor may be open to prosecution does not exculpate the employer/principle contractor. In fact, an employer/principal contractor cannot even contract out of its responsibilities and will be found liable even if its sub-contractors or employees have signed an agreement deeming them solely responsible. ${ }^{41}$

\section{C. "DUE DILIGENCE" DEFINED}

"Due diligence" is simply the exercise of "reasonable care." ${ }^{\text {"42 }}$ It is something more than "specious" or "unbelievable" reasons or "excuses. ${ }^{143}$ As defined in Sault Ste. Marie, "due diligence" is established "if the accused reasonably believed in a mistaken set of facts which, if true, would render the act or omission innocent, or if he took all reasonable steps to avoid the particular event." ${ }^{44}$

"Due diligence" must be displayed in relation to the fulfilment of a duty imposed by law rather than "in relation to the ascertainment of the existence of a prohibition or its interpretation. ${ }^{45}$ In other words, "due diligence" relates to how one deals with factual

R. v. Rold Enterprises Ltd. (12 May 1988) B.C.J. No. 1086 (B.C. Co. Cl.) [unreported] re: exercise of "due diligence" by owner in authorizing use of his motor vehicle.

R. v. The M.T. Barbro (12 April 1991) N.B.J. No. 313 (N.B.Prov.Ct) (unreported) re: pollution under the Canada Shipping Act.

See R. v. Z-H Paper Products Limited (1979), 27 O.R. (2d) 570, 107 D.L.R. (3d) 163 (Ont. H. Ct.). See Varnicolor Chemical Ltd. case, supra, note 36, in which a consultant was charged.

Omtario (Ministry of Labour) v. Helmer Pedersen Construction Ltd., supra, note 22 - mining context. R. v. L.(M.V.) (1988), 62 Alta L.R. (2d) 44, 90 A.R. 164 (Alta. Prov. Cl., Y. Div.).

$R$ v. Jomaa (1987), 83 A.R. 149.

$R$. v. Sault Ste. Marie, supra, note 1 at 1325-26; also R. v. Custeau, supra, note 11 at 13 .

Molis v. R. (1980), 55 C.C.C. (2d) 558, [1980] 2 S.C.R. 356 (S.C.C.), at 364, per Lamer J. Also see R. v. Saulnier (1989), 90 N.S.R. (2d) 77, 230 A.P.R. 77 (N.S. Co. Ct.); R. v. Walker (1989), 91 N.S.R. (2d) 173, 233 A.P.R. 173 (N.S. Co. Ct.). 
circumstances; it will not enable mistake of law ${ }^{46}$ or ignorance of the law ${ }^{47}$ to be used as a defence.

What constitutes "due diligence" is case specific, and the standard of care required to establish the defence depends on the facts of each case, and the particular industry or activity involved. ${ }^{48}$ Basically, the greater the likelihood of harm, and the greater the awareness of the potential danger, the more "due diligence" an accused must exercise in order to escape liability. Thus, only the outer limits of the defence can be stated with any certainty. For example, it is clear that the standard of diligence required for the defence to be operative will fall "short of risking life and limb" and "where an accused chooses in a moment of crisis to deposit a relatively small quantity of a deleterious substance, rather than risk a man's life, he has acted as a reasonable man would have done in similar circumstances and will not be held liable."49

Factual considerations a court will take into account in assessing whether "due diligence" was exercised within a resource exploration operation would include:

(1) the operation: its size, its location, special climatic conditions, inherent risks in the activity or materials used in the activity, the general standard of care common to a particular activity;

(2) the risk of harm: the objective likelihood harm will occur given the operation and activity (as found by the court), whether the facts indicate the company accurately assessed the risks of the harmful act occurring, and the reasonableness of the beliefs of the factors on which the risk was assessed;

(3) the defendant: how much control the defendant had over the events leading to the harm, the degree of knowledge expected of the defendant; and (4) the damage: the degree and magnitude of the harm involved..$^{50}$

Actions amounting to "due diligence" may change with time; what might amount to an appropriate solution at one juncture might not meet "due diligence" standards at a future point in time. Thus, "due diligence" includes keeping abreast of technological change and ensuring equipment is not only in good operating condition, but also meets current

R. v. Richardson (1981), 34 O.R. (2d) 348, 62 C.C.C. (2d) 417 (Ont. H. Ct.); afrd (1982), 39 O.R. (2d) 438, 68 C.C.C. (2d) 447 (Ont. C.A.).

47. Molis v. R., supra, note 45.

58. R. v. Bata Industries Lid., supra, note 31.

44. "Environmental" (1990) C.E.D. (West. 3rd), Part 1, ss. 13 (at 55-45) and V.P. Lalonde et al., "Protecting Directors, Officers and Employees from Liability for Environmental Offences: The Due Diligence Defence" in Environmental Law Issues Confroming the Oil and Gas Industry (Mississauga: Insight Educational Services, 1989) at 46 citing $R$. v. Western Forest Industries Lid. (1978), 9 C.E.L.R. 57 (B.C. Prov. Ct.).

50. These factors are noted in Gary A. Letcher, "Environmental Compliance and Due Diligence in the Canadian Mining Industry", at 7, in The Canadian Institute, Environmental Regulation Compliance Management for Canadian Mining. (Toronto: The Canadian Institute, 1991), and R. Cotton and Donohue, supra note 20, at 53 discussing R. v. Rio Algom Lid. (1988), 66 O.R. (2d) 674, 46 C.C.C.(3d) 242 (Ont.C.A.); R. v. Spicer (1988), 88 A.R. 67 (Alta.Prov.Ct). 
specifications and standards. ${ }^{51}$ In one case, a municipal corporation did not establish the defence where its original and formerly acceptable facility design provided for the discharge of deleterious substances into public waters in the event of a system failure. ${ }^{52}$

"Due diligence" as a defence to direct liability of an employer has been stated as simply taking "every precaution which is reasonable" in the circumstances to "follow the rules". ${ }^{53}$ In some circumstances, "due diligence" may mean retaining consultants or experts when the appropriate level of expertise is lacking internally. ${ }^{54}$

To set up a "due diligence" defence to vicarious liability as an employer, the employer must meet a two-part test. The employer must show "the act took place without the accused's direction or approval, thus negating wilful involvement of the accused, and ... the accused exercised all reasonable care by establishing a proper system to prevent the commission of the offence and ...[took] reasonable steps to ensure the effective operation of the system." ${ }^{155}$ One writer notes that "[m]any trial judges are now reluctant to acquit an accused company unless a due diligence defence convincingly discloses an unavoidable accident." ${ }^{56} \mathrm{He}$ cites, as an example, a 1979 British Columbia Court of Appeal judgment where the Court found that "the length ... the employer must go to will depend on all the circumstances including the magnitude of the damage that will be done in the event of a mistake and the likelihood of there being a mistake." ${ }^{157}$ The Court stated that, because employees were not "infallible people," if the potential consequences are serious it might not be enough "if one does nothing but hire careful people train them carefully and tell them not to [do certain acts]," and that the corporate employer might have to "make adequate provisions in its systems or otherwise" to prevent the damage that may occur "when employees are not as careful as they are told to be."58 "Due diligence" also requires "adequate information and instructions from the company right down to the man on the job. ${ }^{159}$

R. v. Rio Algom Ltd. (1988), 46 C.C.C. (3d) 242, 66 O.R. (2d) 674 (Ont.C.A.); also see D. Saxe, Environmental Offences: Corporate Responsibility and Executive Liability (Toronto: Canada Law Book Inc., 1990) at 171.

52. R. v. Corporation of the District of North Vancouver (1983), 13 C.E.L.R. 60 (B.C.C.A.).

53. Ontario (Ministry of Labour) v. Helmer Pedersen Construction Lid., supra, note 41 dealing with Ontario Occupational Health and Safety Act, R.S.O. 1980, c.32 in the mining context.

See the precedent-setting case of $R$. v. Bata Industries Ltd., supra, note 31, in which the company chairman and chief executive officer was exculpated from liability under the Ontario Environmental Protection Act and The Water Resources Act for chemical seepages from improperly stored drums at a plant because he issued a technical advisory circular and appointed an experienced director to oversee the plant's drum storage facility. Also reported in AL NEWS, supra, note 31. health and safety cases. For example see R. v. BBS Construction Ontario Lid. (1989), (Ont. Prov. Ct., Crim. D.) [unreported].

56. G.A. Letcher, supra, note 50 at 3.

57. R. v. Gulf of Georgia Towing Co., [1979] 3 W.W.R. 84, 10 B.C.L.R. 134 (B.C.C.A.).

s8. R. v. Gulf of Georgia Towing Co., supra, note 57 at 87.

59. V.P. Lalonde et al., supra, note 49 at 45, citing R. v. MacMillan Bloedel Industries Ltd. (1973), 13 C.C.C. (2d) 459 (B.C. Prov. Ct.). 
Strict liability may attach to a principal contractor for the acts and omissions of its subcontractors. ${ }^{60}$ A principal contractor will be required to prove "due diligence" in its efforts to ensure subcontractors comply with legislated standards. This type of "due diligence may, for example, include:

(1) choosing properly qualified subcontractors;

(2) contractually requiring statutory compliance;

(3) providing adequate instructions and information;

(4) providing timely and adequate supervision;

(5) inspecting subcontracted work for compliance. ${ }^{61}$

\section{LEGISLATIVE DEVELOPMENTS}

\section{A. SCOPE OF APPLICATION OF STRICT LIABILITY TO LEGISLATION}

The Sault Ste. Marie decision confines the "due diligence" defence to offences created under "public welfare" or "public interest" legislation. ${ }^{62}$ Public welfare offences are those "which are not criminal in any real sense, but are prohibited in the public interest," and may be "variously referred to as 'statutory,' 'public welfare,' 'regulatory,' 'strict responsibility,' or 'absolute liability."'63 These offences "are not criminal in any real sense," but are civil in nature and "relate to such everyday matters as traffic infractions, sales of impure food, violations of liquor laws, and the like."64

Strict liability offences are violations of "quasi-criminal" statutory requirements, or prohibitions which are part of a regulatory scheme enacted for the health, safety or welfare of the general public. ${ }^{65}$ The penalty for violation may be severe, to ensure protection of the public interest. Prohibitory language importing strict liability commonly includes words such as "no person shall [do X]," or "cause" or "permit"66 [X to happen], and will not clearly indicate that guilt must follow mere proof of the offending acts (or they will be considered absolute liability offences) ${ }^{67}$ Other words which create strict liability offences include "ensure," "strict duty" and "shall be deemed to be in contravention." ${ }^{168}$ Thus far, the Sault Ste. Marie decision (which itself involved pollution

See Sault Ste. Marie, supra, note 1 at 1330-31.

E.J. Brown and D.R. Heckadon, "Environmental Audits: Legal Issues" at 6-7, prepared for discussion of CPA Environmental Law Subcommittee, 12 November 1991.

$R$. v. Sault Ste. Marie, supra, note 1 at 1309-10; also see discussion in Hutchinson, supra, note 6 at 425-27.

R. v. Sault Ste. Marie, supra, note 1 at 1302. The limiting of the application of strict liability to offences under non-criminal regulatory legislation was recently confirmed by the Supreme Court of Canada in its 1991 decision of $R$. v. Wholesale Travel Group Inc. and Chedore, supra, note 19; and see accompanying text.

Sault Ste. Marie, supra, note 1 at 1299.

For a discussion of the difference between "quasi-criminal" and "criminal" offences see M.I. Jeffery, "Environmental Enforcement and Regulation in the 1980's: Regina v. Sault Ste. Marie Revisited (1984) 10 Queens L.J. 43 at 52-54.

$R$. v. Sault Ste. Marie, supra, note 1 at 1327-28.

See discussion of the requirements in $R$ v. Rube (1991), 54 B.C.L.R. (2d) 106 (B.C.C.A.).

Wording in Ontario's Industrial Safety Act: R. v. Z-H Paper Products Limited, supra, note 39. 
legislation) has been applied to a variety of "quasi-criminal" offences under a broad spectrum of statutes, regulations and by-laws. Examples of strict liability offences include those under occupational health and safety legislation, ${ }^{69}$ pollution and environmental legislation (water, ${ }^{70}$ lands and forests, ${ }^{71}$ fish $^{72}$ and wildlife ${ }^{73}$ ), consumer protection legislation, ${ }^{74}$ import and customs legislation, ${ }^{75}$ and motor vehicle legislation, ${ }^{76}$ as well as a miscellany of offences under professional conduct enactments, ${ }^{77}$ liquor prohibition

R. v. Ellis Don-Ltd., supra, note 22: R. v. Richard (1991), 114 N.B.R. (2d) 375 (N.B.Q.B., T.D.); $R$. v. Spicer. supra. note 49; $R$. v. Z-H Paper Products Limited supra, note 39; $R$. v. Napanee (11 May 1990) O.J. No. 931 (Ont. Prov. Ct.) [unreported]; R. v. Dagmar Construction Ltd. (4 October 1989) Doc. No A42/89 (Ont. C.A.); R. v. White (22 December 1988) A.J. No. 1135 (Alta. Q.B.) [unreported]; $R$. v. BBS Construction Ontario Ltd., supra, note 55.

R. v. Panarctic Oils Limited (1983), 43 A.R. 199. 44 A.R. 385 (N.W.T.T.C.); R. v. Shamrock Chemicals Lid., supra, note 33; R. v. Joi-Terra Farms Lid. (1987), 79 N.S.R. (2d) 203, 196 A.P.R. 203 (N.S. Co. Ct.); R. v. The M.T. Barbro, supra, note 38; R. v. Prince George Wood Preserving Ltd. (16 December 1986) B.C.J. No. 2603 (B.C. Co. Ct.) [unreported]; R. v. Van Bidder (5 December 1990) Y.J. No. 232 (Y. Terr. Ct.) [unreported]; R. v. Belliveau (1985), 58 A.R. 334 (N.S.C.A.).

71. R. v. Lewis (1987), 81 N.S.R. (2d) 140. 203 A.P.R. 140 (N.S. Co. C1.).

72. R. v. Starvish (1986), 79 N.S.R. (2d) 136, 196 A.P.R. 136 (N.S.C.A.), rev'g (1986), 76 N.S.R. (2d) 43, 189 A.P.R. 43 (N.S. Co. Ct.); R. v. Scheffer (1990), 96 N.S.R. (2d) 310, 253 A.P.R. 310 (N.S.C.A.); $R$. v. Longmire (1988), 83 N.S.R. (2d) 266, 210 A.P.R. 266 (N.S. Co. Ct.); R. v. Gerhard (1989), 91 N.S.R. (2d) 276, 233 A.P.R. 276 (N.S. Co. Ct.); R. v. Saulnier, supra, note 45; R. v. Saunders (1989), 94 N.S.R. (2d) 224, 247 A.P.R. 224 (N.S.C.A.); R. v. Denton (3 April 1991) Doc. S.C.C. 02391 (N.S.C.A.); R. v. Camphell (13 March 1987) P.E.I.J. No. 35 (P.E.I.C.A.) [unreported); $R$. v. Richards (24 June 1988) B.C.J. No. 1353 (B.C. Co. Ct.) [unreported]; $R$. v. Sterling (1986) (B.C. Co. Ct.) (unreported]; R. v. Boone (1990), 83 Nfld. \& P.E.I.R. 249, 260 A.P.R. 249 (Nfld. S.C., T.D.); R. v. Murray (27 July 1987) B.C.J. No. 1764 (B.C. Co. Ct.) [unreported]; R. v. Ross (1988), 84 A.R. 156 (Nfld. S.C., T.D.); R. v. Belter (1990) (B.C. Co. Ct.) lunreported]; R. v. Anderson (7 February 1990) Nfld. J. No 52 (Nfld. C.A.) [unreported]; R. v. Kariotakis (14 February 1990) B.C.J. No. 283 (B.C. Co. CI.) [unreported]; R. v. Penney (1988), 74 Nfld. \& P.E.I.R. 320, 231 A.P.R. 320 (Nfld. S.C., T.D.); R. v. Wesley (27 June 1986) B.C.J. No. 283 (B.C. Co.Ct.) [unreported].

R. v. Walker, supra, note 45; R. v. Gunn (1987), 72 Nfld. \& P.E.I.R. 100, 223 A.P.R. 100 (P.E.I.S.C., T.D.); R. v. Lakeroad Meats Ltd. (1987), 60 Sask. R. 13 (Sask. Q.B.); R. v. T.(M.) (1988) (N.W.T. Terr. Ct.) [unreported].

R. v. United Buy \& Sell Service B.C. Inc. (1990) (B.C. Prov. Ct.) [unreported]: R. v. Westfair Foods Lid. (1986), 33 B.L.R. 163, 41 Man. R. (2d) 205 (Man. Q.B.); R. v. Rube, supra, note 67; R. v. Feehan (1989), 49 C.C.C. (3d) 392 (P.E.I. S.C., T.D.); $R$. v. Transfer Genetics Lid. (1988) (Ont. Prov. Ct.. Crim. Div.) (unreported].

75. R. v. Ireco Canada II Inc., supra, note 23; R. v. Martin (28 February 1991) Doc. No. CA655/90 (Ont. C.A.) (unreported]: Chahill v. R. (sub.nom Chahill v. Canada) (1988), 18 F.T.R. 37, [1988] 3 F.C. 345, 16 C.E.R. 76 (F.C., T.D.).

R. v. L.(M.V.), supra, note 42; R. v. Sutherland (1990), 55 C.C.C. (3d) 265, 96 N.S.R. (2d) 27 I (N.S. S.C., A.D.); R. v. Blue Sage Transport \& Services Ltd. (1989), 65 Alta L.R. 423 (Alta. Q.B.); R. v. Burge (1988), 72 NId. \& P.E.I.R. 158, 223 A.P.R. 158 (P.E.I. S.C.. T.D.); R. v. Boyde (13 January 1988) Doc. No. Kamloops 30865 (B.C. Co. Ct.) [unreported]; $R$. v. Rold Enterprises Lid. supra, note 37; R. v. Free (1990), 25 M.V.R. (2d) 30, 77 Alta L.R. (2d) 79, 110 A.R. 241 (Alta. Q.B.). 
regulations, ${ }^{78}$ education legislation, ${ }^{79}$ animal protection and child welfare legislation, ${ }^{80}$ and even local dog by-laws. ${ }^{81}$

In contrast, legislation which is purely "criminal" serves to protect individual interests by penalizing individual offenders, rather than securing societal interests. ${ }^{82}$ It usually requires positive proof of some specific mens rea, such as intent, knowledge or recklessness. The penalty imposed for these types of offences is often severe, so that failure to require proof of a specific state of mind, by means either of evidence or inference, would amount to a violation of fundamental justice and constitutional rights. In these cases, the words "wilfully" or "knowingly," ${ }^{83}$ "with intent," or "intentionally" would commonly appear in the statutory provision. Examples of legislation creating these types of criminal offences are the federal Narcotics Control $\mathrm{Act}^{84}$ and the federal Competition Act. ${ }^{85}$

The allocation of federal and provincial jurisdictional authority over various areas of public welfare will be a factor which will affect the applicability of Sault Ste. Marie and the judicial "due diligence" defence. Clearly, legislation which is valid provincial legislation "cannot possibly create an offence which is criminal in the true sense."86 However, if an area of public interest becomes federally regulated, and the regulatory provisions are drafted so as to be penal in nature, quaere whether these offences will be categorized as more "criminal" in nature, thereby rendering judicial "due diligence" impotent as a defence. The issue of legislative jurisdiction is of particular significance in the environmental law area. Given the recent trend toward a stricter, more punitive approach to environmental legislation enforcement, and because such legislation serves to protect the Canadian public at large (as opposed to single individuals or local groups), the issue of whether environmental legislation falls within federal legislative competence is becoming increasingly important. It is notable that the Law Reform Commission of Canada has proposed amendments to the federal Criminal Code ${ }^{87}$ to include "crimes against the environment," and that the Criminal Code already contains the potential for environmental offences under such diverse references as the environment, ${ }^{88}$ criminal

R. v. Piascik, [1990] N.W.T.R. 175 (N.W.T.S.C.).

R. v. Kotelmach, (1989), 76 Sask R. 116 (Sask. Q.B.): R. v. Jomaa. supra, note 43.

R. v. Irish (1 November 1989) O.J. No. 1899 (Ont. Prov. Ct., Fam. D.) (unreported]; R. v. Komarnicki (1991), 116 A.R. 268 (Alta. Prov. Cl., Crim. Div.).

R. v. MacDonald (1988), 5 M.V.R. (2d) 187, 83 N.S.R. (2d) 293, 210 A.P.R. 293 (N.S.C.A.),

$R$. v. Sault Ste. Marie, supra, note 1 at 1312.

lhid.

R. v. Holmes (21 November 1989) B.C.J. No. 2095 (B.C. Co. Ct.) [unreported].

Competition Act, R.S.C. 1985, c. C-34; see Canada v. Pharmaceutical Society (Nova Scotia) (sub nom. R. v. Pharmaceutical Society (Nova Scotia) (1991), 64 C.C.C. (3d) 129, 102 N.S.R. (2d) 222. 279 A.P.R. 222, 80 D.L.R. (4th) 206 (N.S. Sup. Ct., A.D.) rev'g (1990), 59 C.C.C. (3d) 30, 73 D.L.R. (4ih) 500, 32 C.P.R.(3d) 259 (N.S. Sup. Cl., T.D.).

R. v. Sault Ste. Marie, supra, note 1 at 1327.

Criminal Code, R.S.C. 1985, c. C-46.

L.F. Duncan, Enforcing Environmental Law: A Guide to Private Prosecution (Edmonton:

Environmental Law Centre, 1990) at 10-11. 
negligence, ${ }^{89}$ common nuisance ${ }^{90}$ mischief, ${ }^{91}$ dangerous substances, ${ }^{92}$ offensive volatile substances, ${ }^{93}$ and offences against animals. ${ }^{94}$

In addition to categorizing the legislative provisions as "quasi-criminal," prior to assuming that "due diligence" is available, one must also consider whether the statute intends to create absolute liability. Traditionally, in quasi-criminal public welfare cases absolute liability was imposed. Absolute liability offences arise where the legislature, for various reasons, has simply decided guilt should follow mere proof of the statutorily prohibited actus reus, irrespective of fault. A defence of "due diligence" is not available in these cases. Because absolute liability may still exist for some prohibited acts or omissions and, a preliminary determination must be made as to which type of liability will apply. Two examples of legislation creating an absolute liability offence are the federal Coastal Fisheries Protection Act, ${ }^{95}$ and the Canada Shipping Act. ${ }^{96}$

To complicate matters, a single statute may contain both absolute liability offences and strict liability offences. ${ }^{97}$ Moreover, in some cases absolute liability offences will be "read down" to offences of strict liability, as to hold otherwise may offend Section 7 of the Charter. ${ }^{98}$ The Supreme Court of Canada has held that where an absolute liability offence carries the potential penalty of imprisonment, it will be a limitation on the right to life, liberty and security of the person and the right not to be deprived of same except in accordance with the principles of fundamental justice. ${ }^{99}$ Thus, in accordance with the legal presumption of constitutionality, the provision will be "read down" to create strict liability so as to remain constitutional.

Whether an offence will be characterized as strict, rather than absolute, is determined by looking at the legislation's purpose. If it is found to be public welfare legislation, a violation will prima facie be a strict liability offence, unless it can be shown that the

Criminal Code, supra, note 87, ss. 219-221.

Criminal Code, supra, note 87, s. 180.

Criminal Code, supra, note 87, s. 430.

Criminal Code, supra, note 87, ss.79-82.

Criminal Code, supra, note 87, s. 78.

Criminal Code, supra, note 87, ss. 444-447.

Re: provision prohibiting foreign vessels from entering Canadian fisheries waters without approval, sec R. v. Roman (1987), 66 Nfld. \& P.E.I.R. 319, 204 A.P.R. 319, 38 C.C.C. (3d) 385 (Nfld. C.A.). See R. v. Esso Resources Canada Limited, [1983] 46 A.R. 375 (N.W.T., Terr. Ct.) where an oil company was found guilty of discharging a pollutant into the MacKenzie River, contrary to regulations under the Canada Shipping Act. R.S.C. 1970 c. S-9 (as am.). The Court found there was no specific "due diligence" defence in the statute, and defined the offence as one of absolute liability. $R$. v. Feehan, supra, note 74 re: violation of provisions dealing with non-prepackaged goods under the federal Food and Drug Act, R.S.C. 1985, c. F-27.

$R$. v. Cancoil Thermal Corporation and Parkinson (1986), 27 C.C.C. (3d) 295 (Ont. C.A.): $R$ v. Fechan. supra. note 74.

Reference re Section 94(2) of Motor Vehicle Act (British Columbia) (1985), 23 C.C.C. (3d) 289, 24 D.L.R. (4th) 536. [1985] 2 S.C.R. 486 (sub nom. Reference Re Constitutional Question Act (British Columbia)) [1986] I W.W.R. 481 (S.C.C.); R. v. Cancoil Thermal Corporation and Parkinson, supra, note 98. 
legislature clearly intended absolute liability be imposed. ${ }^{100}$ The three primary considerations used to determine whether the offence is one of strict liability are:

(1) the overall regulatory pattern adopted by the

(2) the importance of the penalty; and

(3) the precision of the language used. ${ }^{101}$

\section{B. STATUTORY "DUE DILIGENCE" IN THE 1990's}

Although Sault Ste. Marie embodies the jurisprudential beginnings of strict liability, earlier case law occasionally recognized some form of "less-than-absolute" liability, and certain "quasi-criminal" statutes enacted before Sault Ste. Marie contained specific references to a "due diligence" defence. ${ }^{102}$ "Due diligence" has long been a defence in statutes governing highway and motor vehicle operation, and although the use of strict liability in recent environmental regulation has been judicially encouraged, not all environmental "due diligence" provisions are the result of post-Sault Ste. Marie draughtsmanship. For example, the Ocean Dumping Control Act, ${ }^{103}$ which predates the Canadian Environmental Protection Act ${ }^{104}$ ("CEPA") and whose subject-matter is now contained within CEPA, provided for a defense of "due diligence" in some circumstances.

It is notable that the courts have "generally not differentiated between statutory due diligence and the Sault Ste. Marie due diligence defence." ${ }^{105}$ As a practical matter, however, and subject to the specific wording of the statute, a defendant likely finds it preferable to have the defence outlined in a statute or regulation.

An express "due diligence" defence can now be found in most statutes whose purposes are to protect more modern "populist" values, as these involve a balancing of public and private interests and are more regulatory than criminal in nature. Federal consumer protection and worker safety legislation expressly includes the "due diligence" defence, ${ }^{106}$ as do federal statutes with environmental protection goals. The most notable of these latter statutes are the CEPA ${ }^{107}$ and the Fisheries Act. ${ }^{108}$ Corresponding

R. v. Sault Ste. Marie, supra, note 1 at 1326.

Ibid.

For example, the federal Consumer Packaging Labelling Act, R.S.C. 1970-71-72, c. 41, s. 21(1) in R. v. Westfair Foods Lid., supra, note 74; and the Alberta Highway Traffic Act, R.S.A. 1970 (now R.S.A. 1980 , c. H-7) in R. v. L. (M.V.), supra, notc 42).

S.C. 1974-75-76, c. 55; also see $R$. v. Panarctic Oils Limited, supra, notc 70 re: case dealing with this statute.

S.C. 1988 , c. 22.

G.A. Letcher, supra, note 50 at 6 .

Aeronautics: Section 818(2), Air Regulations, pursuant to Air Act, S.C. 1985, c. 28, as am.; see $R$. v. Pennock (29 June 1987) B.C.J. No. 1799 (B.C. Co. Ct.) [unreported]. Anti-trust (false/misleading advertising): Sections 36, 37.3, Competition Act, R.S.C. 1970, c. C-23 as am.; see R. v. (Wholesale) Travel Group Inc. and Chedore, supra, note 19.

Statutory recognition of the "due diligence" defence is contained in Section 125 of the Canadian Environmental Protection Act, supra, note 104, but the defence is expressly stated to be inapplicable to certain offences: "No person shall be found guilty of an offence under this act other than exercised all due diligence to prevent its commission." 
provincial statutes likewise provide for "due diligence."109 Although a survey of the variety of means by which the "due diligence" defence is statutorily acknowledged is outside the scope of this article, a brief look at the practical results of its statutory inclusion is essential to a complete understanding of Sault Ste. Marie's far-reaching effects. An overview of the decision's implications for industry therefor follows.

\section{PRAGMATIC DEVELOPMENTS IN INDUSTRY}

At first glance, it might seem that provisions creating strict liability would not encourage statutory compliance as much as provisions creating absolute liability. However, the introduction of the "due diligence" defence seems to have had the opposite effect.

First, this defence has been developing at a time when governments and regulatory bodies are taking a firmer approach to the enforcement and prosecution of public welfare offences. Although self-regulation, consultation, and technical and administrative mechanisms have been the chief means through which provincial governments have accomplished environmental regulation, recent statutes, such as the Alberta Environmental Protection and Enhancement Act ${ }^{110}$ contain strict liability provisions which emphasize stricter environmental standards and higher penalties for non-compliance. ${ }^{111}$ Thus, the incentives for voluntary compliance are increasing, in spite of the existence of the "due diligence" defence.

Second, ensuring the availability of a defence against successful prosecution is only one of many reasons industry has found it useful to establish operational standards showing "due diligence." An exercise of "due diligence" may prevent an offence altogether, or reduce the likelihood an offence will occur. When an innocent violation does occur, diligent attempts to comply with legislated standards, together with an undertaking to take remedial action, may avoid the laying of charges. In one reported case, the responsiveness to the suggestions of regulatory officials regarding "preventative measures" and the development of a system for pollution prevention was used to establish a successful "due diligence" defence. ${ }^{112}$

On conviction, "due diligence" may serve to reduce the penalty, or change the nature of the penalty. For example, although due diligence may protect corporate officers from

Ontario Environmental Protection Act, R.S.O. 1980, c. 141; British Columbia Waste Management Act, R.S.B.C. 1982, c. 19; Bill 53, Alherta Environmental Protection and Enhancemem Act, 2d Sess. 22d Leg. Alta., 1991 and specifically s. 206 of Bill 53.

110. Proposed Alberta Environmental Protection and Enhancement Act, supra, note 109.

iil. See S.R. Miller, "Enforcement Under the Proposed Alberta Environmental Protection and Enhancement Act" January 31, 1991 [unpublished], at 1. Also sec Alberta J. Hudec \& J.R. Paulus, "Current Environmental Regulation of the Alberta Oil and Gas Industry and Emerging Issues" (1990) 28 Alta. L. Rev. 171 at 173-174.

112. R. v. Cipa Industries Lid. (1981), 3 F.P.R. (B.C. Prov. Ct.), cited in V.P. Lalonde et al., supra, note 49 at 47. 
large fines or imprisonment, ${ }^{113}$ a showing of "due diligence" by corporate officers can also eliminate the possibility of public humiliation resulting from a corporate violation..$^{14}$ In one case where "due diligence" was not exercised, the trial court ordered the company to issue in the local paper a public apology for the offence, accompanied by pictures of the Board of Directors. ${ }^{115}$ Deterrence has been cited as the most important factor in determining the penalty for corporate violations, with the following factors to be taken into consideration: resulting environmental damage, wealth and size of the defendant corporation, corporate attitude, and criminality of conduct based on the financial advantage sought or obtained, the risks taken and the "worst case" scenario. ${ }^{116}$

A February 1992 Ontario Court of Appeal decision exemplifies why proactive compliance is a preferable approach. In $R$. v. Bata Industries Lid., the Court not only found corporate directors personally liable, it forbade the corporation from paying the fines imposed on the president and a vice-president, but also compelled the corporate defendant to publish the details of the trial in its worldwide newsletter, issue a worldwide technical circular that contained the court decision, and register a warning on the title documents for the contaminated site. ${ }^{17}$ These decisions clearly indicate the intention of the courts to find ways to discourage not only corporations, but also their directors, officers and managers, from ignoring events of non-compliance or from failing to act when such events are within their knowledge and scope of authority.

Indirect benefits of a more positive nature can also be derived by a company through the exercise of "due diligence." By reducing its exposure to prosecution, a corporation may enhance its public image as a responsible corporate citizen, thereby increasing its competitiveness in the marketplace. Establishing "due diligence" in one area (eg. plant construction and operation) may indirectly increase efficiency and reduce costs in another area (eg. reclamation and clean-up on decommissioning). ${ }^{118}$ Documented exercise of "due diligence" may add to the attractiveness of asset divestitures by increasing the confidence of the purchasers in the condition of the assets. Timely "due diligence" may reduce or eliminate the high costs of non-compliance, such as destruction of property or assets, loss of profits, emergency firefighting or damage repair expenses, litigation costs, and increased insurance premiums.

113. "[N]othing appears to seize the attention of both front line workers and management as much as imposing direct responsibility upon an individual." See D. Saxe, supra, note 35 at 107. For a list of penalties imposed for environmental violations, see D. Saxe, supra, note 35, Appendix at 112 et seq.

114. "The stigma of a criminal prosecution, even if there's no jail and no fine is awful. It affects your securities filings, it affects your ability to get a loan, and it's embarrassing." B. Groveman, "Striking Back - Making the Polluter Pay!" (Commentary), (1987) 12 (No.1) Intervenor 6, (address to Canadian Environmental Law Association February 2, 1987); also sce "Prosecuting Polluters You've Got To Be In It To Win" (Editorial), (1987) 12 (No.1) Imtervenor 2.

115. Although this requirement was eliminated on appeal: $R$. v. Panarctic Oils Limited, supra, note 70. re: offence under Ocean Dumping Control Act, S.C. 1974-75-76, c. 55.

116. See the Northwest Territorial Court decisions in R. v. Esso Resources Canada Limited, supra, note 96, and $R$. v. Panarctic Oils Limited, supra, note 70.

117. $\quad R$. v. Bata Industries Ltd., supra, note 48.

118. Some of these reasons are noted by G.A. Letcher, supra, note 50 at 12-13. 
For the forgoing reasons, the pragmatic response of various industries to the availability of the "due diligence" defence to public welfare legislation has been swift and strong. Corporations have, on a proactive basis, developed corporate policies to reflect the corporation's commitment to the public good, established "compliance programs" to "provide on-going evidence of reasonable preventative care,"119 and have undertaken ongoing risk assessments, voluntary audits, and education programs. ${ }^{120}$ This corporate activity has been accompanied by revision of the documentation drafted to effect commercial transactions involving property governed by strict liability provisions. The following is a brief outline of the measures undertaken by industry to reduce liability and penalties for environmental offences, using the Alberta natural resource industry as an example.

\section{A. CORPORATE POLICIES}

Corporate policies existed before Sault Ste. Marie, but now commonly include commitments to becoming a "green" corporate citizen. Although a corporate policy statement may provide the corporation and its employees with a clearer picture of the corporation's broad objectives and goals, the corporation runs the risk that it thereby imposes on itself additional non-legislated standards of conduct. ${ }^{121}$ A corporation's "non-compliance" with its own stated objectives, which objectives are normally broadlyworded and somewhat visionary, could evidence its lack of "due diligence" which might not otherwise exist. However, most resource corporations have chosen to adopt corporate policies as a means of clearly communicating both the corporation's commitment to the environment and health and safety, and the responsibility of employees for environmental compliance.

\section{B. COMPLIANCE PROGRAMS}

To develop an appropriate, workable compliance program is no small task, let alone to ensure that ongoing compliance actually occurs. It was reported that as of October 31, 1990, "some twenty-four federal departments [were] responsible for the implications of more than fifty statutes," all of whom were "supposed to work in harmony with ten provinces that collectively have approximately one hundred environmental laws on their books." ${ }^{22}$ It is no wonder that every major natural resource company in Alberta has an entire department dedicated solely to deciphering legislation, investigating internal procedures, policies and operations, and transforming them into those that constitute environmental compliance.

R. Cotton \& M. Donahue, supra, note 20 at 11.

For a list of practical recommendations for compliance programs and voluntary audits, see R. Cotton, "Environmental Audits: The Role of Legal Counsel and Solicitor Client-Privilege" (1989) 18 Can Council Int. L. 215. Also see Cotton, supra. note 4, at 3-9,14-16; and R. Cotton \& M. Donahue, supra, note 20 at 49 .

121.

See Kirby v. R. (1972), 2 F.P.R. 22 (B.C. Co. Ct.), cited in V.P. Lalonde et al., supra. note 49 at 46 , in which case the failure of a company to meet its own operational requirements negated a due diligence defence.

122. R. Cotton \& M. Donahue, supra, note 20 at 51, quoting federal numbers from Toronto Star newspaper article (31 October 1990). 
To establish "due diligence" through a compliance program, 3 elements must exist:

(1) procedures, preferably written, must be in place to effectively comply with the directives of all relevant statutes, regulations, by-laws, guidelines, policies and permits or approval certificates;

(2) the procedures must have been followed at the time in question; and

(3) the procedures must have been appropriate, meeting up-to-date industry standards and information. ${ }^{123}$

It should again be noted that a compliance program might reduce a corporation's liability, rather than eliminate its culpability entirely.

\section{VOLUNTARY ENVIRONMENTAL AUDITS}

An environmental audit, defined as a "formalized system of inspection of all potential risks," was first recognized as indicia of "due diligence" in 1983. ${ }^{124}$ Environmental audits undertaken on a voluntary, proactive basis to identify and eliminate environmental concerns are now one of the chief means industry uses to evidence its "due diligence." In conjunction with an assessment of the risk of non-compliance, they often are a component of a corporation's environmental compliance program. ${ }^{125}$ Environmental audits have also become an integral part of the increasing number of asset trades, acquisitions and divestitures by the natural resource industry, instigated both as a precaution by careful purchasers and lenders, and for the purpose of accurately assessing property values.

Audits provide the written record that is necessary to substantiate "due diligence." 126 Although environmental audits have the potential to both generate and document incriminating evidence of non-compliance and to trigger an inspection or other enforcement activity, its growing use by the corporate sector indicates industry considers its advantages to outweigh its potential negative consequences. To overcome the danger of self-incrimination resulting from environmental audits, companies commonly try to employ "solicitor-client privilege" as a means of protecting the corporation from having its damning information used against it. ${ }^{127}$ However, this legal tool is of limited value for two reasons: "solicitor-client" privilege, in its true sense, does not apply; and Canadian environmental legislation indirectly eliminates this common law defence.

\footnotetext{
123. R. Cotton, supra, note 4 at 11-12.

124. R. v. Placer Development Lid., supra, note 35 at 51. Also see section 2(c) of this article and accompanying notes.

125. See R. Cotton \& M. Donahue, supra, note 20 at 51-52. [brief discussion].

126. R.M. McLeod, "Environmental Protection Legislation: Personal Liability of Officers and Directors" (1988) 5 Bus. \& Law 20 at C-7: and E.J.Brown \& D.R. Heckadon, supra, note 61 at 4.

127. For a more thorough discussion of this area, see E.J. Brown \& D.R. Heckadon, supra, note 61. For a partial list of practical things to do to try to invoke the privilege see R. Cotton, supra, note 4 at 14 16. Also see R. Cotton, "Environmental Audits, the Role of Counsel and the Question of Privilege" in Canadian Bar Association, Corporate Environmental Responsibility and Liability (Toronto: Ontario Continuing Legal Education, 1987).
} 
In Canada, there are two types of solicitor-client privilege: "solicitor-client communications" and "trial investigatory" privileges. Solicitor-client communications are for the primary purpose of seeking or providing legal advice, and attract absolute privilege. ${ }^{128}$ "Trial investigatory" privilege protects from disclosure written information prepared by the client or solicitor for the purpose of, or within the course of, anticipated or existing litigation. Voluntarily prepared audits would usually fall outside the traditional definitions of either type of privilege. First, although the existence of pending litigation may not be an essential element of solicitor-client privilege under modern Canadian law (so long as there is a communication, made in confidence, to obtain or provide legal advice ${ }^{129}$ ), the dominant purpose of most audits is not to obtain or give legal advice. Second, most audits are not prepared in contemplation of litigation. Only in unusual audit cases, therefore, will privilege be available. In one rare example, on an Alberta chambers application, the Master reportedly extended privilege to an environmental audit, but in this case, the corporate legal department, suspecting a problem, had hired independent auditors to conduct a second audit for the specific purpose of rendering legal advice. ${ }^{130}$

Although a "privilege of self-critical analysis" appeared to be developing in the United States, the courts have severely curtailed its growth. ${ }^{13 t}$ The "privilege of self-critical analysis" is basically a United States' "work product" privilege, similar to the Canadian "trial investigatory" privilege. Unlike "trial investigatory privilege, "work product" privilege is not an absolute privilege and may be defeated by a show of necessity for the information on the part of the opposition. The "privilege of self- critical analysis" has been severely constrained and qualified by United States courts. ${ }^{132}$ Likewise, "attomey-

Pursuant to the "dominant purpose test," only of the dominant purpose of a document is to provide legal advice will the document be privileged: see Nova v. Guelph (1984), 50 A.R. 199, also discussed in E.J. Brown \& D.R. Heckadon, supra, note 61 at 28.

129. See Re: Director of Investigations and Research and Canada Safeway Limited (1972), 26 D.L.R. (3d) 745 (B.C. S.C.) dealing with the right of exumination of privileged documents under the federal Combines Investigation Act. For a discussion of this arca of the law, see E.J. Brown \& D.R. Heckadon, supra, note 61 at 22-26.

Reference is made to a case handled by Scott Miller, in-house counsel for Petro-Canada, but the accuracy of this statement is unknown: see E.J. Brown \& D.R. Heckadon, supra, note 61. Also see Appendix to E.J. Brown \& D.R. Heckadon, supra, note 61, by D.R. Heckadon entitled "Environmental Audits \& Solicitor Client Privilege: A Survey of Corporate Viewpoints" wherein one person interviewed noted: "The best people to solve compliance problems are not lawyers, therefore, its [sic] very difficult to argue that the audit was performed for the lawyers [sic] use."

131. $\quad$ Bredice v. Doctors Hospisal Inc. (1970), 50 F.D.R. 249 (D.C.C.) aff'd (1973) 479 F.(2d) 920 (Dist. C. Circ.); ASARCO Inc. v. National Labour Relations Board (1986) 805 S. 2d 195; Barefield v. Chevron U.S.A. Inc. (1987), (U.S. Dist. Ct., N. Dist. Ca.) [unreponed]. Also see "The Privilege of Self-Critical Analysis" (1983) 96 Harv. L. Rev. 1083; and E.J. Brown \& D.R. Heckadon, supra, note 61 at 29-31. It is notable that, to the knowledge of the writer, as of January 1989, the "privilege of self-critical analysis" had only been applied to hospital committee meeting minutes, certain internal investigation reports (such as police department internal reports and a railroad accident investigation). and Title VII equal employment opportunity forms submitted to the United States Government. For example, "self-evaluative privilege" has only been found in regard to subjective information (note objective data) generated within a legally required (but internal) review or evaluation where such review served the public interest but where public disclosure of such review might jeopardize the candidness of the information sought: see E.J. Brown \& D.R. Heckadon, supra, note 60 at 29-32 for a discussion of "self-evaluative" privilege in the United States. 
client privilege," akin to Canadian "solicitor-client communications privilege," has been ineffective in protecting internally generated information from discovery. For example, a 1990 decision of the New York Supreme Court Appellate Division held that documents prepared by a law firm as part of an internal investigation for its corporate client were not exempt from discovery on grounds of attorney-client privilege. ${ }^{133}$

Not only are voluntary audits likely to fall outside the purview of privilege, statutory provisions may preclude an argument of privilege by implication. For example, the federal CEPA and some provincial environmental legislation provide expressly for the disclosure of information to government officers. ${ }^{134}$ Although information gathered for an "investigation" may require a search warrant or court order, whereas information obtained in an "inspection" may not, in either case a corporation may be required to make its documentation relating to an environmental audit available.

In the absence of privilege, there are practical precautions a corporation may take to reduce its exposure. ${ }^{135}$ It can record its technical audit data in a factual, observational (as opposed to interpretive or conclusion-drawing) manner on forms separate from other environmental information, ensure a knowledgeable expert is present at each inspection, maintain accurate records of the inspection, adequately screen the inspectors to ensure the "inspection" is not an "investigation," and, if information is actually taken in the course of an investigation without a search warrant or court order (thus being illegally obtained evidence), seek recourse to the courts to disallow the information from being used as evidence in a prosecution. ${ }^{136}$ Although making an audit highly confidential might reduce corporate exposure, many corporations instead choose to distribute widely the results of their audits, in the belief that less long-term risk will result if problems are addressed and eliminated prior to their discovery by enforcement officers. ${ }^{137}$

An argument based on the Charter right against self-incrimination has been discussed as another possible means of protecting corporations from prosecution based on voluntary

Spectrum Systems International Corporation v. Chemical Bank (1990), 157 A.D. (2d) 444 (N.Y. S.C., A.D.) unlike "work product" privilege, attorney-client privilege affords a party absolute protection. Attomey-client privilege is only extended to those who have the authority to make, substantially make, or control a corporate decision, does not protect publicly available information, and is lost if the information is distributed widely throughout the corporation and this loses its confidentiality.

Canadian Environmental Protecrion Act, S.C. 1988, c. 22, s. 125; and, for Ontario examples, Ontario's Environmental Protection Act, Pesticides Act, The Water Resources Act (and Bill 148, 1988). For a general discussion of environmental inspections and investigations, see R.M. McLeod \& J.B. McMeekin, "Environmental Inspections and Searches" (1989) 6 (No. 8) Bus. \& L. 59.

This list is not exhaustive. See R.M. McLeod \& J.B. McMeekin, supra, note 134 at 60 . Also see D.T.A. Cote, "Ministry Investigations Under the Ontario Occupational Health and Safety Act Developing an Effective Strategy" and J.W. Adams, "What the Police Would Give for the Powers of a Provincial Officer!" both in Insight Educational Services, Environmental Health and Safety Investigations, (Mississauga: Insight Press, 1989). "Some Thoughts on the Search and Seizure Powers of the Emironmental Protection Act, R.S.O. 1980. CH. 141", and J.W. Adams, supra, note 135. 
audit data. However, the usefulness of this argument has been discounted; the right against self-incrimination only applies to oral testimony. ${ }^{138}$

Brief mention should be made of the federal Enforcement and Compliance Policy for the Canadian Environmental Protection Act. ${ }^{139}$ This statement commends the use of environmental audits "as a management tool" and "intends to promote their use by industry and others," ${ }^{140}$ but notes that "environmental audit reports must not be used to shelter monitoring, compliance or other information that would otherwise be accessible to inspectors under the Canadian Environmental Protection Act." ${ }^{141}$ This policy thus provides little comfort to corporations fearing self-incrimination through their environmental audit process.

\section{RISK ASSESSMENT}

The availability of the "due diligence" defence will depend on the accuracy of the individual or corporation in foreseeing possible harm and assessing the risk. Thus, corporate risk analysis is an important preliminary activity in establishing corporate compliance programs, conducting voluntary environmental audits, and the like. The undertaking of a risk assessment may itself constitute "due diligence" if such assessment is "based on what an appropriately qualified expert might reasonably predict." 142

\section{E. EDUCATION}

With the increase in the number of charges being laid against individuals and corporations alike, ${ }^{1+3}$ educating employees and managers is a necessary first step in both avoiding legal action and establishing a "due diligence" defence. In fact, the education

See P. Edwards, "Confidentiality in Environmental Auditing" (1990) I Jour. Envir. L. and Prac. I, at 49.

139. Minister of the Environment, "Canadian Environmental Protection Act Enforcement and Compliance Policy", (Ottawa: Environment Canada, May 1988) |hereinafter "Enforcement and Compliance Policy"].

1+10. Enforcement and Compliance Policy, supra, note 139 at 29.

141. Enforcement and Compliance Policy, supra, note 134.

142. $\quad R$. v. Placer Development Ltd., supra, note 35 at 377 , per Stuart J.

14.1. In R. Cotton \& M. Donahuc, supra, note 20 at 77 , the writers state:

MOE Investigations and Enforcement Branch statistics at July 341, 1990 disclose that 416 charges were laid against individuals or companies in 1989 90 as compared to 149 in 1985-86. The total number of prosecutions in 198990 was 265 as compared to 86 in 1985-86. This indicates a changing attitude towards prosecutions. It may be only an early warning signal of things to come. In the United States there has been a dramatic increase in the number of prosecutions of middle and upper-level management personnel for the illegal activities of the company. In addition, environmental offences are increasingly being treated as criminal. Whether this trend will be reflected in Canada remains to be seen." 
of employees or contractors may be part of the fulfilment of the second of the two-part test for employer "due diligence." ${ }^{\text {"144 }}$

Even the courts have recognized the importance of education by incorporating it into the sentencing for environmental offences. In a 1985 case, the sentence imposed by the Yukon Territorial Court was the preparation of a corporate manual dealing with common environmental problems encountered in all phases of inland mineral exploration in the Yukon and Northwest Territories. ${ }^{145}$

\section{F. COMMERCIAL DRAFTING}

Since the late 1980's, trades, acquisitions and divestments of resource properties have become a principle activity of western Canadian natural resource companies. The existence of environmental audit reports, the vendor's desire to eliminate future environmental liability, and the purchaser's desire to not acquire latent liabilities has resulted in innovative, if lengthy, wordsmithing by commercial draftsmen. Representations, warranties and indemnities in purchase and sale agreements, clauses granting purchasers the right to inspect and conduct environmental audits, and confidentiality provisions are a few types of provisions which may need redrafting as a result of the existence of a "due diligence" defence. Careful vendors will also want to ensure they have maintained their right to retain and, where necessary, use and reproduce copies or originals of documents and records which may be needed to establish a "due diligence" defence at some time in the future.

\section{CONCLUSORY COMMENTS}

Strict liability seems both a timely and logical development in the law. As our awareness of our interdependence has grown, we have experienced increasing regulation in areas where survival depends on cooperative effort. Strict liability may be seen as a judicial response to our desire to find a realistic balance between individual responsibility and public welfare. Whereas the prima facie establishment of liability allows for the expeditious enforcement of public welfare legislation, the corresponding "due diligence" defence infuses a degree of fairness into the process. At minimum, the adoption of strict liability is indicative of the Supreme Court of Canada's willingness to adapt to the realities of the times by addressing the evidentiary problems inherent in decisions involving public welfare offences. ${ }^{146}$ Its incorporation into public welfare legislation, particularly in the environmental area, has encouraged proactive self-regulation without deterring fair enforcement of regulated standards.

The eagerness of Canadian courts to embrace a middle ground between criminal liability and absolute liability for public welfare offences is shown by the rapid

\footnotetext{
14. Education may be part of a "proper system to prevent the commission of the offence" and may amount to one of the "reasonable steps to ensure the effective operation of the system": per Dickson J. in $R$. v. Sault Ste. Marie, supra, note 1 at 1331.

145. $\quad R$. v. Placer Development Lid., supra, note 35.

146. Hutchinson, supra, note 6 at 423-24.
} 
assimilation of strict liability into case law. Moreover, the inclusion of the "due diligence" defence in public welfare legislation evidences the acceptance of strict liability by Canadian regulatory regimes. Irrespective of the weakness of its historical basis, or the fact it is a clear example of judicial law-making, Sault Ste. Marie is a decision which has, and will continue to have, far-reaching effect on the development of Canadian public welfare law. 